Wyrok Sądu Kościelnego we Włocławku (c. Grzęźlikowski) z 13.10.1997 r. w sprawie o nieważność małżeństwa z tytułu poważnego braku rozeznania oceniającego co do istotnych praw i obowiązków małżeńskich (kan. 1095, n. 2 KPK)

Ius Matrimoniale 8 (14), 231-241

2003

Artykuł został zdigitalizowany i opracowany do udostępnienia w internecie przez Muzeum Historii Polski w ramach prac podejmowanych na rzecz zapewnienia otwartego, powszechnego i trwałego dostępu do polskiego dorobku naukowego i kulturalnego. Artykuł jest umieszczony w kolekcji cyfrowej bazhum.muzhp.pl, gromadzącej zawartość polskich czasopism humanistycznych i społecznych.

Tekst jest udostępniony do wykorzystania w ramach dozwolonego użytku. 
Ius Matrimoniale 8 (14) 2003

\section{Wyrok sądu kościelnego we Wlocławku (c. Gręźlikowski) \\ z 13.10.1997 r. w sprawie o nieważność małżeństwa \\ z tytułu poważnego braku rozeznania oceniającego co do istotnych praw i obowiązków małżeńskich (kan. 1095, n. 2 KPK)}

\section{Przebieg sprawy}

Powód zbuntowany na system polityczny wyjechał nielegalnie $z$ Polski do Austrii w lipcu $1981 \mathrm{r}$. Miał wtedy 21 lat i studiowal na politechnice. Po ponad rocznym pobycie w Austrii, pod koniec 1982 r. wyjechał do Nowej Zelandii, gdzie była możliwość podjęcia pracy. Po zamieszkaniu u starszego Polaka i podjęciu pracy zaczął tęsknić za rodziną i krajem. Chciał wrócić, ale nie mial na powrót środków finansowych i bał się. Sytuacja taka doprowadziła, że przeżywał depresję, był bardzo samotny, załamany i zagubiony, nie przygotowany do życia w zupełnym odosobnieniu od najbliższych, a jego brak dojrzałości i przygotowania do takiego życia przytlacza go i przerasta. Zupelnie załamany i nie wiedzący co z sobą zrobić poznaje w rok później - pod koniec 1983 r. - pozwaną. Podjęcie tej znajomości chwilowo poprawia jego stan psychiczny, jednak nie na długo. Znajomość ta mu nie odpowiada, ale na jej prowadzenie nalega pozwana, która pokochała powoda. Milości tej nie odwzajemnia powód. Robi wszystko, ażeby znajomość ta nie doprowadziła do zawarcia małżeństwa, jednocześnie w pełni nie zdaje sobie sprawy, że prowadzenie znajomości doprowadzi do zawarcia małżeństwa. Nie chciał - jak twierdził - być $\mathrm{z}$ pozwaną w małżeństwie, a $\mathrm{z}$ drugiej strony jest mu samemu jeszcze gorzej. Zastraszony, przerażony i bezradny, tęskniący za krajem i dziewczyną, którą tam zostawil, rodziną, z którą mial kontakt listowny, załamany psychicznie, szantażowany przez pozwaną, twierdzi, że na skutek powstalej sytuacji, swej niedojrzałości osobowościowej nie zdawal sobie sprawy czym jest i do czego zobowiązuje małżeństwo. Twierdził nadto, że nie potrafil właściwie i dojrzale osądzić zaistniałej sytuacji prowadzącej go do zawarcia małżeństwa, co więcej, że nie był zdolny do krytycznej oceny stanu rzeczy na skutek przeżyć i tęsknoty za 
krajem i swoimi bliskimi, doznań i załamania psychicznego oraz swej niedojrzałości. Zeznawal również, iż nie był w stanie na skutek swojej sytuacji w jakiej się znalazł do praktycznego sądu, a jego sfera wolitywna osłabiała władze poznawcze, które nie zdawały sobie sprawy na co się decyduje i czym jest malżeństwo w jego sytuacji. Zawarł je tylko i wylącznie ze względu na sytuację $w$ jakiej się znalazł $\mathrm{i}$ wielkie napięcie emocjonalne. Na skutek tego - jak twierdzil - nie potrafił wtedy dokonać należytego osądu zaistniałej i trudnej jego sytuacji, miał ograniczoną wolę i krytyczne poznanie oraz nie był zdolny do należytej oceny przedmiotu zgody małżeńskiej i jej swobodnego wyboru, mimo że zawierając małżństwo miał prawie 24 lata. Małżeństwo kościelne zostało zawarte przez powoda dnia 22 stycznia 1984 r. w katedrze św. Patryka w Auckland w Nowej Zelandii.

Małżeństwo stron od samego początku nie układa się najlepiej. Strony przeprowadzają się do Australii, następnie Anglii, mieszkają jakiś czas na prośbę powoda (około pól roku) w Polsce, potem na nowo przeprowadzają się do Anglii, gdyż pozwana w Polsce nie chce mieszkać, czego bardzo pragnął powód. Nadto powód robi wszystko, ażeby pozostać w Polsce. To doprowadza do konfliktów małzeńskich, poróżnienia i zerwania $\mathrm{w}$ konsekwencji wspólnoty malżeńskiej. W małżeństwie strony miały syna i córkę, które pozostały przy pozwanej. W sumie małżeństwo stron trwało okolo ośmiu lat i gdyby nie problem niechęci pozwanej do zamieszkania i jej dominacji w małżeństwie, jak twierdzi powód, małżeństwo to trwałoby nadal.

Prośbę powodową o nieważność swego małżeństwa wniósł powód 6 marca 1996 r. przebywając już w Polsce na terenie diecezji włocławskiej. Pozwana w tym czasie mieszkała w Anglii (diecezji Portsmouth). Z braku kompetencji, w myśl przepisów kan. 1673,4 KPK, Sąd Wlocławski uzyskał pozwolenie na prowadzenie procesu od Trybunału diecezji Portsmouth $z$ dnia 14 czerwca $1996 \mathrm{r}$. Prośbę powodową przyjęto do instrukcji 2 lipca $1996 \mathrm{r}$. W postępowaniu dowodowym przesłuchano strony, powoda poddano badaniom psychologiczno-psychiatrycznym przez biegłego sądowego, który przedłożyl Sądowi orzeczenie sądowo-psychiatryczne. Przesluchano także czterech świadków, dwóch powołanych świadków (siostry pozwanej) nie zdołano przesłuchać, gdyż odmówiły złożenia zeznań. Akta sprawy były publikowane w lipcu 1997 r., po wniesieniu przez powoda uwag, dekretem z dnia 25 sierpnia $1997 \mathrm{r}$. zamknięto postępowanie dowodowe i przystąpiono do wyrokowania sprawy. Wyrok stwierdzający ważność małżeństwa stron zapadł 13 października 
1997 r. Po złożeniu obszernie uzasadnionej apelacji przez powoda, akta sprawy zostały przekazane Trybunałowi II instancji - Metropolitalnemu Trybunałowi Gnieźnieńskiemu, który ponownie rozpatrzył sprawę i dekretem z dnia 24.04.1998 r. potwierdził wyrok Sądu I Instancji.

\section{Motywy prawne}

Do rozpatrywanej sprawy małżeńskiej mają zastosowanie następujące przepisy prawa kanonicznego: ,niezdolni do zawarcia malżeństwa sa ci, którzy majq poważny brak rozeznania oceniajqcego co do istotnych praw i obowiqzków malzeńskich wzajemnie przekazywanych i przyjmowanych" (kan. 1095,2 KPK). Dla wyrażenia zgody małżeńskiej w świetle powyższego przepisu - jako przyczyny sprawczej małżeństwa wymaga się pewnej dojrzałości sądu, inaczej rozeznania proporcjonalnego do natury samego małżeństwa. Zgoda małżeńska tylko wówczas będzie wyraźnie i ważnie wyrażona, jeśli zawierający małżeństwo posiada taką dojrzałość sądu, która jest proporcjonalna do natury małżeństwa. Stąd prawodawca kościelny jako niezdolnych do zawarcia małżeństwa dyskwalifikuje tych, którzy mają poważny brak rozeznania oceniającego co do istotnych praw i obowiązków malżeńskich wzajemnie przekazywanych i przyjmowanych. Chodzi o sytuacje, w których osoba zawierająca małżeństwo dotknięta jest poważnym brakiem wspomnianego rozeznania oceniającego, tzn. nie jest zdolna do krytycznej oceny stanu rzeczy na skutek przeżyć, doznań, załamań psychicznych czy patologii osobowości. Trzeba bowiem pamiętać, co podkreśla orzecznictwo Roty Rzymskiej, że proces psychologicznego dochodzenia do praktycznego sądu zawierającego małżeństwo w odniesieniu do zawieranej umowy malżeńskiej jest bardzo ważny i istotny. Stan psychiczny zawierającego małżeństwo zakłóca sferę wolitywną, jednocześnie osłabia władze poznawcze, stanowiąc przeszkodę w zaistnieniu rozeznania oceniającego. Stąd bardzo ważnym elementem przy zawieraniu małżeństwa jest dojrzałość sądu, czyli rozeznania oraz zdolność do krytycznej oceny istoty umowy małżeńskiej.

Gdy chodzi o sam przedmiot rozeznania oceniającego, to odnosi się on do istotnych praw i obowiązków małżeńskich wzajemnie przyjmowanych i przekazywanych. Zgoda tylko wówczas będzie ważnie wyrażona, jeśli nupturient jest zdolny do należytej oceny jej przedmiotu oraz swobodnego wyboru. Przy ocenie tych kryteriów dużą rolę mają 
biegli sądowi, którzy winni ocenić naturę zakłócenia, jej rodzaj oraz skutki. Do biegłych należy wskazanie, kiedy w psychicznej strukturze osobowości miało miejsce zachwianie harmonii uniemożliwiającej właściwe rozeznanie oceniające. Może to być spowodowane różnymi członkami, które powodują niestałość, sugestywność, zmienność afektywną, niezdolność ponoszenia nawet malych niepowodzeń $w$ stanie napięć emocjonalnych. Zmniejszają one często, a w wypadkach skrajnych, uniemożliwiają właściwy proces dochodzenia do podjęcia rozważnego sądu co do zawarcia małżeństwa.

\section{Motywy faktyczne}

\section{A/ Twierdzenia i zeznania powoda:}

„Wyjechałem z Polski w lipcu 1981 r. /.../ byłem odważny, chciałem wyjechać i żyć normalnie /.../ wyjechałem do Austrii, a potem podjąłem decyzję o wyjeździe do Nowej Zelandii /.../ Tam podjąłem pracę, ale zacząłem tęsknić za krajem, rodziną, było mi bardzo źle, mimo, że sam tego chciałem /.../ Pozwaną poznałem przypadkowo we wrześniu 1982 r. nie znała polskiego /.../ Miała jakiegoś chlopaka, narzeczonego, zaproponowała jednak, abym spotykał się z jej siostrą /.../W Polsce ja miałem dziewczynę, pisałem do niej, ale ona nie odpowiadała /.../ Załamany, nie mający w nowym świecie nikogo /.../ nie chciałem chodzić z siostrą pozwanej, ani ona ani pozwana nie były w moim guście /.../ Jednak pozwana powiedziała mi, że zrywa $\mathrm{z}$ narzeczonym i zaczyna chodzić ze mną /.../ było to dla mnie zaskoczenie, nie myślałem o małżeństwie i nigdy poważnie tej znajomości nie brałem /.../ Uważałem, że wrócę do Polski i tutaj się ożenię /.../

Pozwana postawiła mnie jednak $w$ takiej sytuacji, że nie miałem żadnego wyjśscia, wykorzystała moją sytuację /.../ ja nie zdawałem sobie sprawy ze wszystkich konsekwencji tego chodzenia /.../ Nie potrafiłem jej odmówić, a jednocześnie nie kochałem jej /.../ Byłem na łasce losu, na obczyźnie, nie wiedziałem co robić, moja wola i rozum nie były w pełni samodzielne, poddałem się bezkrytycznie woli pozwanej, byłem zastraszony i ubezwłasnowolniony /.../ Mój konsens małżeński był na mnie wymuszony i wynikał z sytuacji w jakiej się tam znalazłem /.../ Moje otępienie, załamanie nie pozwalały mi być sobą /.../

W małżeństwie czułem się źle, byłem od niej uzależniony, żona o wszystkim decyduje, ja muszę być cichy i pokorny /.../ Pozwana miata 
trudny charakter /.../ była wybuchowa, nerwowa /.../ despotyczna /.../ Chciałem się osiedlić w Polsce, ona tego nie chciała /.../ wyraziła tylko zgodę na miesięczny przyjazd /.../ Nie pozwalała uczyć nasze dzieci języka polskiego /.../ Po ciąglych nieporozumieniach i konfliktach nasze małżeństwo rozpadło się w roku 1993 /.../."

\section{B/ Twierdzenia i zeznania pozwanej:}

„Gdy poznałam powoda czuł się zadowolony, cieszył się, że uniknął ciężkich czasów w Polsce /.../ żył nadzieją krótkiego urlopu w Polsce /.../ ale nie było mowy o stałym pobycie /.../ Kochałam powoda, chciałam za niego wyjść i nie przymuszałam go do zawarcia małżeństwa /.../ Może i ja bardziej chciałam tego małżeństwa, ale przecież jak mogłam go zmusić /.../ On był inteligentnym człowiekiem, wiedzial co robi /.../ jak może obecnie mówić, że nie chciał tego małżeństwa, że jego wola i rozum były zniewolone /.../ Pozwany jest hipokrytą, czuję się obrażona, skoro nie był w naszym małżeństwie szczęśliwym, to dlaczego mieliśmy dwoje pięknych dzieci /.../ Wszystko wzięło złe obroty kiedy przyjechaliśmy do Polski, wówczas podjął powód decyzję pozostania w Polsce, ja nie chciałam bo obiecal mi, że będziemy mieszkać nie w Polsce /.../ Zaproponowałam mężowi zamieszkanie w Anglii, a spędzanie urlopów w Polsce, ale nie chciał /.../ Skoro nie był szczęśliwym w małżeństwie, to dlaczego wcześniej ode mnie nie odszedł /.../ Powodem rozpadu naszego małzeństwa było to, że ja nie chciałam pozostać w Polsce /.../."

\section{C/ Zeznania świadków:}

1. Matka powoda:

„Syn mial wyjechać tylko na wakacje do Austrii, a jak się okazało pozostał tam, a potem znalazł się w Nowej Zelandii /.../ Australii i Anglii /.../ Wiem, że syn bardzo tęsknit po wyjeździe za Polską, za rodziną /.../ było mu ciężko /.../ Nie pisał, że ma tam jakąś dziewczynę /.../ i nagle w jednym $z$ listów napisał, że ślubuje, że pozwana tego bardzo chce, nawet zdjęcia pozwanej mi nie przysłał /.../Potem napisał, że ślubował bo szukał ciepła, że nie mógł oprzeć się jej namowom, że nie przemyślała sprawy do końca, jakby nie wiedział do końca co robi i jak to będzie dalej /.../ czynil to na jej polecenie, wbrew sobie /.../."

2. Matka pozwanej:

„Córka pokochała powoda, widziała go jako swego męża, on też chciał z nią być, bo byl samotny. Faktycznie przed ślubem nie okazywał 
jakiegoś uczucia wobec córki, ale nie mówił też, że nie chce ślubować/.../ Na obczyźnie czuł się źle, dlatego córka pocieszała go, umilała mu życie i pobrali się /.../ Córka go do małżeństwa nie zmuszała, a on wiedział co robi /.../ Trudno mi uwierzyć i przyjąć, że nie wiedział co robi, albo że nie zdawał sobie sprawy czym jest i do czego zobowiązuje małżeństwo /.../."

3. Ciotka powoda:

„Powód był człowiekiem inteligentnym, zdolnym /.../ Sam podjął decyzje o opuszczeniu Polski /.../ Gdy znalazł się na obczyźnie poczuł się samotny, załamany, pisał listy, że jest mu źle, że chciałby wrócić, ale nie ma jak /../. O pozwanej nie pisał za wiele, po ślubie dopiero pisał i mówit, że nie zdawał sobie sprawy do końca co robi zawierając to małżeństwo, jakby sytuacja w której się znalazł spowodowała jego nieprzemyślane zachowanie /.../ Według mnie był w tym małżeństwie pantoflarzem i nic nie miał do powiedzenia /.../ Ona miała ciężki charakter lubiła koczowniczy tryb życia, jemu to nie odpowiadało, chciał osiedlić się w Polsce, ale ona nie chciała /....."

4. Siostra powoda:

„Brat dość często pisal listy do nas jako do rodziny /.../ Pisał, że po kilku miesiącach ona - pozwana i jej rodzina zaproponowali mu małżeństwo, nie potrafil się z tego wycofać, pierwszym razem jej odmówil, to zrobila mu wielką awanturę /.../ On był subtelnym i dobrym czlowiekiem, delikatnym, nie chciał jej urazic /.../ Moim zdaniem zawierał to małżeństwo tylko dlatego, że był samotny i na obczyźnie czuł się źle /.../ Mam wrażenie, że nie przemyślał decyzji zawarcia małżeństwo do końca, bo jego wola i myślenie nie byly w pełni wolne i samodzielne, uzależnione od sytuacji w jakiej się znalazł tam $z$ dala od rodziny $\mathrm{i}$ bliskich /.../ Małżeństwo się rozpadło, bo ona miała zły charakter, byli ze sobą chyba 12 lat, szukali ciągle lepszych warunków życia, a pozwana nie chciała osiedlić się w Polsce /....."

\section{D/ Orzeczenie sądowo-psychologiczne Bieglego Sądowego:}

„Powód ogniskowych zaburzeń psychicznych nie przejawia /.../Osobowość powoda zwarta z minimalnymi cechami rozszczepieniowymi /.../ nadto osobowość powoda przejawia pewne cechy osobowości bierno-zależnej, które są stałym i zasadniczym elementem w jego osobowości. Cechy te jednak nie naruszają struktury osobowości powoda, dojrzałości sądu czy władz poznawczych /.../ Nie jest dotknięty anomaliami osobowościowymi /... jest to inteligentny, umysłowo rozwinięty ponad przeciętną człowiek /.../W chwili zawierania związku małżeńskiego mimo, że znaj- 
dował się w trudnej dla siebie sytuacji, tęsknił za krajem i rodziną, że przeżywał pewnego rodzaju stan depresyjny, należy przyjąć, że sytuacja ta nie spowodowała zakłóceń w jego wolności wewnętrznej, poznawczej i wolitywnej /.../ cechy osobowości powoda i sytuacja w jakiej się znalazt nie naruszały struktury jego osobowości, dojrzałości sądu i wladz poznawczych. Sfera wolitywna i emocjonalna nie osłabiała władz poznawczych /.../ stąd należy przyjąć, że w chwili zawierania małżeństwa powód miał rozeznanie oceniające i mógł właściwie i należycie ocenić czym jest i do czego zobowiązuje małżeństwo, które chciał zawierać z pozwaną /.../.

\section{Wnioski decyzyjne}

Kolegium Sędziowskie Trybunału Włocławskiego po zapoznaniu się z materiałem dowodowym na który składało się zaprzysiężone zeznanie stron, czterech świadków (matki powoda i pozwanej, siostry i brata powoda) oraz orzeczenie sądowo-psychiatryczne o powodzie, po przeanalizowaniu uwag powoda przedstawionych po publikacji akt sprawy oraz uwag przedwyrokowych obrońcy węzła małżeńskiego, po wnikliwej analizie zgromadzonego materiału dowodowego i szerokiej dyskusji na sesji wyrokowej Kolegium Sędziowskie wyprowadziło następujące wnioski, jako przesłanki do decyzji wyrokowej:

A/ Powód przebywając w Nowej Zelandii faktycznie czuł się samotny, załamany, tęsknil za Polską i swoją rodziną, to mogło powodować u niego pewne braki natury emocjonalnej i w integralności osobowości, jednak nie na tyle ażeby nie zdawał sobie sprawy czym jest i do czego zobowiązuje małżeństwo. To, że postanowił sam dobrowolnie opuścić Polskę i wyjechać nielegalnie za granicę świadczy i wskazuje, że był człowiekiem zdecydowanym na przyjęcie wszelkich niedogodności, świadczy też o jego dojrzałości, samodzielności i zdecydowaniu. Człowiek niedojrzały i nie samodzielny zapewne nie podjąłby decyzji ucieczki z kraju swego zamieszkania, w trakcie trwania studiów, które przebiegaly bez problemów i trudności.

B/ W zeznaniach powód stwierdzil, że chciał spotykać się i być z pozwaną, bo to lagodziło jego samotność, jednak nie widział jej jako swojej żony. Nie oznacza to, że nie wiedział czym jest małżeństwo, albo że nie zdawał sobie sprawy do czego znajomość ta prowadzi, tym bardziej, że pozwana wyznawała mu, że go kocha i chce być jego żoną. Pozwana zeznała, że nie mówił jej nigdy powód, że nie chce $\mathrm{z}$ nią być, 
a wręcz przeciwnie, wiedział, że dla niego zerwala $z$ pewnym Anglikiem i temu się nie przeciwstawiał. Byl zadowolony jak $z$ nią przebywal i nigdy nie mówil jej, że nie chce tego małżeństwa. Potwierdza też dojrzalość i zdecydowanie powoda co do zawarcia malżeństwa. Nadto nie dostrzega u niego niedojrzalości osobowościowej czy patologii, które powodowałyby brak świadomości czy osądu czym jest i do czego zobowiązuje małżeństwo. Jest ona przekonana, że powód ślubował szczerze i prawdziwie, dobrowolnie $z$ pełną świadomością co robi. Był też zdolny - zdaniem pozwanej - od strony osobowościowej, dojrzałościowej do zawarcia małżeństwa i podjęcia obowiązków małżeńskich.

C/ Orzeczenie biegłego psychiatry (psychologa) było jednoznaczne. Wskazywało ono na integralność i dojrzałość osobowościową powoda, zdolność do należytego ocenienia czym jest małżeństwo i wyrażenia konsensu małżeńskiego. Wskazało tylko na pewne cechy osobowości bierno-zależnej, które są elementem stałym i zasadniczym w jego osobowości. One jednak - zdaniem biegłego - nie naruszały struktury osobowości, dojrzałości sądu czy władz poznawczych. Biegły sądowy wykazał też, iż sytuacja w jakiej się znalazł powód nie powodowala zaklócenia jego wolności wewnętrznej, poznawczej i wolitywnej. Sfera wolitywna i emocjonalna nie osłabiała - zdaniem biegłego - władz poznawczych. Nie był on i nie jest też dotknięty poważniejszymi anomaliami osobowościowymi, był i jest człowiekiem inteligentnym, kulturalnym, co świadczy i jego zdolności do krytycznego poznania przedmiotu małżeństwa i obowiązków małżeńskich. Sytuacja w jakiej się znalazł powód tej zdolności nie przekreślała i nie eliminowała, najwyżej minimalnie ją zagluszała. Osobowość powoda - jak twierdzi biegły - byla w chwili zawierania malżeństwa ustrukturalniona.

D/ Świadkowie występujący w procesie w swoich zeznaniach nie potwierdzili wprost twierdzeń powoda co do jego braku rozeznania oceniającego co do praw i obowiązków małżeńskich. Wskazali, że był człowiekiem inteligentnym, zrównoważonym, powolnym, mało czasami zdecydowanym, trochę smutnym i tęskniącym za ojczyzną i rodziną, a jego rzekome przeżycia nie powodowały, że nie wiedział co robi zawierając małżeństwo $\mathrm{z}$ pozwaną, jak też nie zawierał małżeństwa tylko i wyłącznie na sytuację w jakiej się znalazł. Matka powoda zeznała, że pisał do niej w liście, że raczej niechętnie zawiera to małżeństwo, ale go chce, ponieważ nie będzie sam.

E/ Sędziowie uznali, iż powód miał rozeznanie oceniające co do praw i obowiązków malżeńskich wzajemnie przekazywanych i przyjmowa- 
nych. Wiedzial czym jest malżeństwo i do czego zobowiązuje. Zapewne przeżycia powoda na obczyźnie, tęsknota, załamanie, sytuacja w jakiej się znalazł nie byly dla niego latwe, szczególnie początkowo, ale trudno przypuszczać i nie ma na to dowodów, ażeby samodzielnego, dojrzałego $i$ decydującego się na wyjazd za granicę mężczyznę powalily z nóg na tyle, ażeby nie wiedział co się z nim dzieje, albo też nie był zdolny do krytycznej oceny stanu rzeczy. Zapewne stan psychiczny i emocjonalny powoda w chwili zawierania malżeństwa był nadszarpnięty, ale nie na tyle ażeby zakłócał sferę wolitywną, czy też ją osłabiał na tyle, aby nie wiedzial czym jest małżeństwo i do czego zobowiązuje i co za sobą niesie, jak też powodowal, że nie mial on rozeznania proporcjonalnego do natury zawieranej umowy małżeńskiej. Miał też dojrzałość sądu, co powodowało iż mógł wystarczająco uświadomić sobie prawa i obowiązki małżeńskie, przyjąć je i przekazać pozwanej.

F/ Materiał dowodowy wykazał także właściwe podchodzenie powoda do obowiązków małżeńskich, dbanie o wspólnotę małżeńską, a różnice dotyczące szczególnie kwestii zamieszkania stron w Polsce przy niechęci pozwanej do stałego pobytu w Polsce spowodowały nieporozumienia i rozpad małżeństwa. Nadto zbytnia władczość pozwanej i jej despotyzm zniechęciły powoda do tego małżeństwa i zdecydowały, że postanowił on odejść od żony - pozwanej. Jednak sytuacja zaistniała po zawarciu małżeństwa, trudności oraz pojawiające się niechęci po stronie powoda nie mogą być przyczyną nieważności małżeństwa, bowiem Trybunał Kościelny nie udziela rozwodu, ale stwierdza jego ważność lub nieważność zawarcia. Momentem decydującym więc w rozpatrywanej sprawie małżeńskiej jest, w myśl przedmiotu sporu, czy powód w chwili zawierania małżeństwa $\mathrm{z}$ pozwaną miał rozeznanie oceniające co do praw i obowiązków małżeńskich. Analiza materiału dowodowego wskazała jednoznacznie, iż takim rozeznaniem oceniającym się odznaczał, a władze poznawcze i wolitywne były w stanie właściwie ocenić zaistniałą sytuację i w sposób właściwy i ważny wyrazić zgodę małżeńską.

\section{Orzeczenie}

Biorąc pod uwagę motywy prawne i faktyczne, które zostaly przedłożone w niniejszej sprawie małżeńskiej, Sąd Kościelny Diecezji Włocławskiej, jako Trybunał I Instancji, w składzie podanym wyżej, mając tylko Pana Boga przed oczyma, po wezwaniu Ducha Świętego, w sprawie 
o nieważność małżeństwa N. N., na pytania procesowe postawione w zawiązaniu sporu, a mianowicie czy zaskarżone małżeństwo jest nieważne $\mathrm{z}$ tytułu braku rozeznania oceniającego po stronie powoda co do praw i obowiązków małżeńskich (kan. 1095, 2 KPK) odpowiedział na tak postawione pytanie negatywnie, stwierdzając, że: nieważność zaskarżonego malżeństwa nie została udowodniona $z$ tytułu braku rozeznania oceniającego co do istotnych praw i obowiązków malżeńskich po stronie powoda.

Po orzeczeniu przez Sąd Wloclawski ważności malżeństwa stron, powód wniósł apelację do Trybunału Gnieźnieńskiego podważając racje kolegium sędziowskiego i podtrzymując swoje twierdzenia o braku rozeznania oceniającego co do praw i obowiązków małżeńskich. Zażądał powołania nowego biegłego sądowego i ponownego rozpatrzenia sprawy. Prosił, aby Trybunał II instancji ponownie podjął próbę przesłuchania sióstr pozwanej.

Trybunał Gnieźnieński przychylił się do prośby powoda i postanowił ponownie rozpatrzyć sprawę na nowym stopniu. Ponownie poddano powoda badaniu psychologicznemu przez biegłego sądowego. Podjęto próby przesłuchania dwóch wcześniej powołanych świadków, które nie przyniosły pozytywnych rezultatów. Trybunał II instancji potwierdzil wyrok Sądu I instancji podając w swoim uzasadnieniu, że nie ma podstaw ażeby uznać, iż powód w chwili zawierania malżeństwa z pozwaną posiadal brak rozeznania oceniającego co do powagi i znaczenia praw i obowiązków małżeńskich. Stan psychiczny i osobowościowy powoda oraz okoliczności kojarzenia się małżeństwa, jego zawieranie, przebieg i przyczyny rozpadu - zdaniem Trybunału II instancji - upoważniają do stwierdzenia, że zgoda małżeńska powoda była skuteczna i ważna. Trybunał Gnieźnieński zasugerował ponowne, ewentualne rozpatrzenie sprawy z tytułu symulacji konsensu małżeńskiego po stronie powoda.

Sentence of church court in włocławek coram Gręźlikowski

in case for nullity of marriage in virtue of lack of judging discernment regarding matrimonial rights and duties (can. 1095,2)

\section{Summary}

Plaintiff brought a suit against his matrimony contracted with N. on 22nd of January 1984 in Saint Patrick's Cathedral in Auckland in New Zealand. N. in virtue of lack of judging discernment regarding matrimonial rights and duties on his side (can. 1095, 
2 Code of Canonical Proeedings) suggesting that in was caused by fact that being on emigration in New Zealand, missing the cauntry of origin and famili, being mentally woebegone and being depressed, he had restricted will and critical cognizance and was not able to have evaluotion of matrimonial agreement subject and its free choice. He also thought that because of arisen situation and due to his individualistic immaturity in moment of contracting the matrimony, he had lock of judging discernment regarding the matrimonial rights and dubes. He lodged a complaint for nullity of marriage tu the tribunal of his place of residence in March 1996. Defendant was living in England in that time. Tribunal Wloclawek obtained - accarding to canonic regulations 1673, 4 Code of Canonical Proceedings - a permission to wunduct a case from the tribunal of defendant's place of residence.

Hearing of evidence induded hearing of the parties, witnesses and examination of the plaintiff by psychologist expert appointed by the wurt, who issued an opinion. Confronting the legal motives submitted in case with actual real motives, after taking the cognizance of plaintiff's notes after publishing the files of a case and before - sentence notes of the defender of matrimonial union, the board of judges passed a sentence in favour of validity of appealed marriage. It was found that: 1. plaintiff could be really actually mentally depressed, emotionally trembling, he missed his country and family, however that stale was not as strong and serious to make him not to realize the fact of what the marriage was; 2 . facts that he left Poland by himself and chose emigration by himself indicate that he was self - dependent and individualistically mature; 3 . lack of discernment was not confirmed by testimonies of defendant and witnesses as well as circumstances of marriage contracting, its course and actual reasons of marriage breakdown; 4. expert appointed by the court found the plaintiff individualistically mature and found no reasons that would cause the plaintiff to have of ability of due judgment of what the matrimony is and which obligations it put him under as well as ability to express matrimonial consent; 5 . plaintff's cognitive and volitive powers were able to evaluate correctly the resulted situation, correctly express matrimonial consent and express matrimonial consent in correct and volid way.

Second Instance Tribunal from Gniezno confirmal a sentence of Tribunal form Wlocławek suggesting the plaintiff to possibly lodge a complaint for nullity of marriage in virtue of simulation of matrimonial condent on his side. 